\title{
Present Situation of Teaching Elementary Science in the Primary School of Dhaka City: An Investigation
}

\author{
Mirza Md. Hasan ${ }^{1, *}$, Md. Abul Ehsan ${ }^{2}$ \\ ${ }^{1}$ Post Graduate Student, Department of Pre- Primary and Primary Education, Institute of Education and Research, Dhaka, Bangladesh \\ ${ }^{2}$ Professor, Department of Pre- Primary and Primary Education, Institute of Education and Research, Dhaka, Bangladesh \\ *Corresponding author: mirzamdhasan@gmail.com
}

Received September 10, 2013; Revised December 16, 2013; Accepted December 25, 2013

\begin{abstract}
Main objective of this study was to find out the present situation of teaching strategies practiced in the elementary science classrooms as well as the knowledge, skills and classroom activities and assessment procedure used for Elementary Science in the primary schools of Dhaka city. The study was descriptive in nature. The researcher intends to use both qualitative and quantitative approaches for collecting and analysis data. From 295 primary school of Dhaka city only 5 schools, 10 teachers and 10 students were selected by Stratified sampling, Simple Random Sampling and purposive sampling. It was found from the study that, Most of the teacher uses question-answer method and lecture method as classroom teaching and learning method, do not use lesson plan properly, could not properly apply elementary science teaching methods perfectly and most of the teachers also do not use the teaching aid properly.
\end{abstract}

\section{Keywords: present situation, teaching, elementary science, primary school, Dhaka city}

Cite This Article: Mirza Md. Hasan, and Md. Abul Ehsan, "Present Situation of Teaching Elementary Science in the Primary School of Dhaka City: An Investigation." American Journal of Educational Research 1, no. 12 (2013): 576-582. doi: 10.12691/education-1-12-1.

\section{Introduction}

At Primary level, all student of Bangladesh have to study Bangla and English literature along with elementary science subject. In grades 1 and 2, natural and social environments are taught together and there are no textbooks for the children in these grades. The teachers have to teach the subject following the teacher's guide on environmental studies developed by experts and published by the National Curriculum and Textbook Board (NCTB). In grades 3 to 5 , science is taught as environmental science and the basic composite science subject like Physics, Chemistry, Biology for each of the grades [6]. Elementary science at the primary level could be an excellent one because Bangladesh is the victim of global environmental problems, climate changes, and natural disasters [6]. But the fact is, in the primary level the quality of education specially science education is not satisfactory for the country as a whole. Following are the main reason for the poor quality of science education at the primary level: lack of qualified teachers, poor school facilities (classroom, library, playground) etc. According to the Handbook of Research in Science Education Research in Asia (2010), science is taught everywhere in Bangladesh using traditional teacher centered methods with less importance paid to student participation. The teachers encourage the students in rote learning [6]. Moreover, with the introduction of new textbooks in 2011, assessment of student learning in science was proposed with only subjective (essay) test items and these types of test were incorporated into the exercises in each chapter in the science textbooks. Although the curriculum has been updated, the evaluation system has not been changed to meet the expectation of new curricula. As a result, once the most sought-after subject at primary, secondary, college, and university levels in the country, science is losing its appeal in an alarming shift of choice. If we cannot stop this trend, we will very soon be facing a situation where science and scientific enterprises in our country will be seriously jeopardized, leaving us as a nation of traders.

This study was conducted to find out the present situation of teaching strategies practiced in the elementary science classrooms as well as the strengths and weaknesses of teaching Elementary Science in the primary schools of Dhaka city.

\section{Significance of the Study}

At the postgraduate level, research in pure and applied science is conducted in different public universities in Bangladesh but research in science education are rare in Bangladesh. Moreover, The research also found that science is still taught everywhere in Bangladesh using traditional teacher-centered methods with less importance paid to student participation. The teachers encourage the students in rote learning. On the other hand, Miah (2011) said that the quality of education is not satisfactory for the country as a whole [9]. Moreover, the study will try to 
explore the present situation of teaching strategies practiced in elementary science classrooms as well as the strengths and the weaknesses of teaching Elementary Science in the primary schools of Dhaka city. So, the relevant educators, teachers, parents, students and concerned authorities would be benefited from the findings of the study.

\section{Research Questions}

This study tried to figure out the answers of the following questions:

a. What is the present situation of knowledge, training and classroom activities of the Elementary Science teachers of Dhaka City?

b. What is the present situation of teaching methods and strategies practiced in the Elementary Science classrooms of Dhaka City?

c. What kind of Assessment procedures are used for Elementary Science teaching?

\section{Limitations of the Study}

Though, lots of efforts were put down to make this study a success, there were some limitations in this study. Such as, for this study a small size sample was selected compared to the required sample size. Also, the schools in Dhaka city were closed due to religious festivals. When the schools were open again, the teachers and students were under a pressure to finish the syllabus within the academic time schedule left. So, when the teachers and students were interviewed, they were always very much in hurry and cautious about their answers. They sometimes tried to give ideal answers to the question or act differently in the classroom situation.

\section{Reviews of Related Literatures}

\subsection{Effective Methods for Science Teaching}

According to constructivism teaching strategies science teachers should use student centered method [7]. Methods of teaching such as cooperative learning, group discussion and use of a learning cycle support the construction of knowledge by students. Students must have the opportunity to build on prior knowledge and maximize social interactions with other students in order to negotiate meaning. It has been found that most students do indeed begin with an interest in science in general however over the years it fades away. Interestingly, the major factor for this decline is the manner in which science is taught [4]. The onus lies with the teachers to make science more desirable. Often, science teachers are not equipped in terms of knowledge and techniques to impart science education effective [8]. Using aids while teaching science is important for many reasons. According to Raven, [11] First, people tend to not remember what they're told if they don't have a visual to remember it by (especially if it's information they aren't highly motivated to remember). Secondly, Students who are not academically inclined automatically tune out when a teacher is standing in the front and droning on and on about a topic. Lastly, using demos allows students to see scientific equipment being used - some of which they may not have a chance to use them . Demos show students exactly how certain concepts were discovered. Moreover, Largely missing from science classrooms, especially large lecture courses, is formative assessment, which is intended to provide feedback during learning exercises to both students and instructors, so that students have an opportunity to revise and improve the quality of their thinking and instructors can tailor instruction appropriately.

\subsection{Elementary Science in Previous Researches}

A study from Bangladesh [5] found that about $88 \%$ of science teachers in Dhaka city had general academic qualifications but $55 \%$ of them had no professional qualifications. Sultana (2008) conducted a study to determine the teaching learning activities of elementary science classrooms in the primary schools of Gazipur district. The objective of her study to find out what methodology does a science teacher uses in the science classrooms as well as students' achievement level. In her study, she found that most of the teachers' uses traditional lecture method to teach science. Most of the teacher uses charts, pictures and textbooks to instruct the students. But, students' achievement level is not satisfactory [11]. Begum (1981) conducted a study to determine the attitudes of grade 5 students towards environment studies. She reported that most of the students had positive attitudes towards the study of environmental studies [2].

\subsection{Elementary Science in Primary Curriculum 2011}

Bangladesh government has taken another step ahead to build a new and improved curriculum for Primary Education in 2011. However, the position of elementary science on the new curriculum is

\subsubsection{Elementary Science as a Compulsory Subject}

The new curriculum of primary education proposed a compulsory subject titled "Elementary Science”. It was previously known as "Introduction to Environment: Science”. On this subject 18 terminal competencies have been set and it is expected that a learner will acquire these competencies after completing this subject. These competencies are distributed gradually in all the five grades. The methods proposed for teaching elementary science are observation method, demonstration method, group work, project method, heuristic method and question-answer method. Proposed teaching aids are Charts, graphs, pictures, posters, real life instruments, blackboard, models, radio, television, computer etc. In terms of assessment techniques, formative assessment is suggested along with summative assessment.

\section{Methodology}

The study was descriptive in nature. The researcher intends to use both qualitative and quantitative approaches for collecting information from both secondary and primary resources in Dhaka city. There are 295 
Government primary schools in Dhaka city. All the teachers and students of these schools are the population of this study. From the large number of school, teachers and students, five government primary schools are choosen by Stratified Sampling (SS) method. The Study covered all the 12 educational thanas of Dhaka city. These thanas were at first divided into two stratas: 6 Thanas of Dhaka south and 6 thanas of Dhaka north. From these 6 thanas of Dhaka south, 3 thanas were selected using a Simple Random Sampling (SRS) method. From these 3 thanas 3 schools were selected from each thana using a SRS (Simple Random Sampling) method. 2 more schools were chosen as a sample from Dhaka north using the same sampling method. The ten elementary science subject teachers and ten students were selected by purposive sampling, to complete the study within assigned time. To maintain the validity and reliability of data, a triangulation method and piloting of tools were engaged for collecting data. Observation checklist, Interview and document analysis used as a tool for collecting data. Data was collected by the researcher himself by taking consent from the respondent. For analyzing the collected data, data organization, data coding and data analysis had been done respectively. Both qualitative and quantitative technique of data analysis are used for making a strong support for findings. While conducting the research the researcher maintained high ethical consideration.

\section{Analysis of Data}

\subsection{Situation of Teachers' Knowledge, Training and Classroom Activity}

From the collected data it is found that, in every school $(n=5)$, elementary science teachers are trained and they have professional degrees (B. Ed/M.Ed). Moreover, a significant number of teachers class teachers (55.5\%) discoursed that they have to take 6 to 7 classes, which they claimed as high teaching load. A great majority of Teachers (66.6\%) informed that the distribution of classes in the school routine is made considering the teachers' subject knowledge and skill. School routine is also prepared after discussion in the teachers' meeting (55.5\%). Teachers' teaching experience is also considered (33.3\%) while only $11.1 \%$ teachers opined in favor of head teacher's desire. Some opines (11.1\%) that class is distributed by the Headmaster and some other teachers. Others (22.2\%) said that it is also based on the number of teachers. They have to take the classes as there were no sufficient teachers. Within this teaching load teachers' and students were asked to give their opinions regarding teachers' teaching activities in the classroom. Their responses are shown in the Table 7.1.

Table 7.1. Teachers' Teaching Activities in the Classroom

\begin{tabular}{|c|c|c|c|c|c|c|c|}
\hline \multirow{2}{*}{ Teaching Activities } & \multirow{2}{*}{ Ratings } & \multicolumn{2}{|c|}{ CT $(n=09)$} & \multicolumn{2}{|c|}{ St $(n=10)$} & \multicolumn{2}{|c|}{$\mathrm{CO}(\mathrm{n}=10)$} \\
\hline & & No & $\%$ & No & $\%$ & No & $\%$ \\
\hline \multirow{3}{*}{ 1. Teacher gives lecture } & Always & - & - & 2 & 20 & 4 & 40 \\
\hline & Sometimes & 7 & 77.7 & 7 & 70 & 6 & 60 \\
\hline & Never & 2 & 22.3 & 1 & 10 & - & 0.0 \\
\hline \multirow{3}{*}{ 2. Teacher use question answer method } & Always & 7 & 77.7 & 6 & 60 & 7 & 70 \\
\hline & Sometimes & 2 & 22.3 & 4 & 40 & 3 & 30 \\
\hline & Never & - & - & - & - & - & 0.0 \\
\hline \multirow{3}{*}{ 3. Teacher appreciates while students answer correctly } & Always & 9 & 100 & 10 & 100 & 10 & 100 \\
\hline & Sometimes & - & - & - & & - & 0.0 \\
\hline & Never & - & - & - & & - & 0.0 \\
\hline \multirow{3}{*}{ 4. Teacher creates opportunity for group discussion } & Always & 5 & 55.5 & 2 & 20 & 2 & 20 \\
\hline & Sometimes & 4 & 44.5 & 7 & 70 & 5 & 50 \\
\hline & Never & - & - & 1 & 10 & 3 & 30 \\
\hline \multirow{3}{*}{ 5. Teacher gives special alteration to weak students } & Always & 9 & 100 & 9 & 90 & 10 & 100 \\
\hline & Sometimes & - & - & 1 & 10 & - & 0.0 \\
\hline & Never & - & - & - & - & - & 0.0 \\
\hline \multirow{3}{*}{ 6. Teacher uses chalk board } & Always & 6 & 66.66 & 7 & 70 & 7 & 70 \\
\hline & Sometimes & 3 & 33.34 & 3 & 30 & 3 & 30 \\
\hline & Never & - & - & - & - & & 0.0 \\
\hline \multirow{3}{*}{ 7. Teacher maintains class discipline } & Always & 9 & 100 & 9 & 90 & 6 & 60 \\
\hline & Sometimes & - & - & 1 & 10 & 4 & 40 \\
\hline & Never & - & - & - & - & - & 0.0 \\
\hline \multirow{3}{*}{ 8. Teacher tries to make attentive students towards their lesson } & Always & 8 & 88.89 & 7 & 70 & 3 & 30 \\
\hline & Sometimes & 1 & 11.11 & 2 & 20 & 7 & 70 \\
\hline & Never & - & - & 1 & 10 & - & 0.0 \\
\hline
\end{tabular}

From Table 7.1 it is clear that all categories of respondents stated that, also found in classroom observation, most of the teacher uses question-answer method during classroom teaching and learning. The teacher and student's opinion also matched with the case of using the lecture method but it did not match with the classroom observation report. While $70 \%$ teacher and student claim that the teacher sometimes use lecture method, $40 \%$ of classroom observation report declined the fact. According to them most of the time teachers try to maintain class discipline and make students' attention towards their lesson. They also appreciate students while they give correct answer to questions. However, a significant number of respondents also reported that teachers do not give special attention to attract students towards lesson and create opportunity for group 
discussion which was also found while classroom observation. As a pre- preparation Majority of the teachers (70\%) told that they use lesson plan while others were unable to show their lesson plans. The teachers' were asked to show their lesson plan. From their lesson plan it is found that most of them prepare a short lesson plan.

\subsubsection{Teachers' Knowledge and Skill}

The teachers and students were asked to rate the teachers subject knowledge and skill on a 5-point scale. Their ratings are shown in Table 7.2.

Table 7.2. Ratings on the Teachers' subject knowledge and skill

\begin{tabular}{|c|c|c|c|c|c|}
\hline \multirow{2}{*}{ Teaching Activities } & \multirow{2}{*}{ Ratings } & \multicolumn{2}{|c|}{$\mathrm{CT}(\mathrm{n}=09)$} & \multicolumn{2}{|c|}{ St $(n=10)$} \\
\hline & & No & $\%$ & No & $\%$ \\
\hline \multirow{5}{*}{ 1. Teacher's capability of making the student understand } & Very Much & 5 & 55.5 & 8 & 80 \\
\hline & Much & 4 & 44.5 & 2 & 20 \\
\hline & To some extent & - & - & - & - \\
\hline & Little & - & - & - & - \\
\hline & Very Little & - & - & - & - \\
\hline \multirow{5}{*}{ 2. Teachers' capability of answering questions correctly } & Very Much & 6 & 66.6 & 7 & 70 \\
\hline & Much & 3 & 33.4 & 3 & 30 \\
\hline & To some extent & - & - & - & - \\
\hline & Little & - & - & - & - \\
\hline & Very Little & - & - & - & - \\
\hline \multirow{5}{*}{$\begin{array}{l}\text { 3. Teachers' capability of applying the elementary science related } \\
\text { teaching methods }\end{array}$} & Very Much & 3 & 33.4 & 8 & 80 \\
\hline & Much & 6 & 66.6 & 1 & 10 \\
\hline & To some extent & - & - & 1 & 10 \\
\hline & Little & - & - & - & - \\
\hline & Very Little & - & - & - & - \\
\hline \multirow{5}{*}{ 4. Teachers' capability of motivating the students } & Very Much & 9 & 100 & 9 & 90 \\
\hline & Much & - & - & 1 & 10 \\
\hline & To some extent & - & - & - & - \\
\hline & Little & - & - & - & - \\
\hline & Very Little & - & - & - & - \\
\hline
\end{tabular}

The Table 7.2 indicates that maximum teachers (55.5\%) have the capability of making the student understand the subject and their opinion has been supported by a majority (80\%) of students. It is also found most of the teachers (66.6\%) has the capability of answering questions correctly which is also supported by $70 \%$ students. But, the opinion of teacher and student did not match in the case of proper application of teaching methods. While fewer teachers (33.4\%) believe that they can apply elementary science teaching methods perfectly, most of the students (80\%) are saying that the teachers can apply with a great deal. However, almost all the teacher and student opine that elementary science teachers motivate the students regarding science learning.

\subsection{Situation of Teaching Methods and Techniques used in the Classroom}

This section analyses the respondents' opinion on teaching learning strategies used by teachers along with effective methods for elementary science teaching.

Table 7.3. Ratings on the use of teaching learning strategies

\begin{tabular}{|c|c|c|c|c|c|c|c|c|c|}
\hline \multirow{3}{*}{ Items } & \multicolumn{9}{|c|}{ Ratings \% } \\
\hline & \multicolumn{3}{|c|}{ Never } & \multicolumn{3}{|c|}{ Sometimes } & \multicolumn{3}{|c|}{ Always } \\
\hline & CT & St & $\mathrm{CO}$ & $\mathrm{CT}$ & St & $\mathrm{CO}$ & CT & St & $\mathrm{CO}$ \\
\hline 1. Teacher gives only one way lecture & 22.3 & 10 & 0 & 77.7 & 70 & 60 & - & 20 & 40 \\
\hline 2. Teacher uses question-answer technique & - & - & 0 & 22.3 & 40 & 30 & 77.7 & 60 & 70 \\
\hline 3. Teacher dictates from text books & - & - & - & 22.3 & 30 & - & 77.7 & 70 & 100 \\
\hline 4. Teacher appreciates student for correct response & - & - & - & - & - & - & 100 & 100 & 100 \\
\hline 5. Teacher gives group work & - & 10 & 30 & 44.5 & 70 & 50 & 55.5 & 20 & 20 \\
\hline 6. Students participate in group work & - & - & 30 & 33.4 & 40 & 50 & 66.6 & 60 & 20 \\
\hline 8. Teacher gives special attention to weak students & - & - & - & - & 10 & - & 100 & 90 & 100 \\
\hline 9. Teacher summarizes lesson at the end. & - & - & - & 22.3 & 40 & 20 & 77.7 & 60 & 80 \\
\hline
\end{tabular}

It reveals from Table 7.3 that most of the school teachers (77.7\%) mainly use question-answer method during classroom teaching. In addition, they sometimes use the lecture method $(77.7 \%)$. On the other hand, the majority of teachers $(77.7 \%)$ dictates from the textbooks in comparison to school teachers. It is interesting to note that all the school teachers always appreciate students for their correct responses. But, some teachers (55.5\%) always arrange a group discussion as a method of teaching while others (44.5\%) do it sometimes. All teachers provide individual help to students and all of them also give attention to weaker students. Most of the teachers (77.7\%) also summarize lesson at the end. However, most of these opinions of teachers have been supported by their students and the data of classroom observation. 
In addition, teachers were asked to name the teaching method used by them in elementary science teaching. The name discoursed by them is provided in Table 7.4.

Table 7.4. Name of the teaching methods used by the teacher

\begin{tabular}{|l|c|c|}
\hline \multirow{2}{*}{ Name of the method } & \multicolumn{2}{|c|}{ CT $(\mathrm{n}=09)$} \\
\cline { 2 - 3 } & No. & $\%$ \\
\hline 1. Demonstration & 4 & 44.4 \\
\hline 2. Problem Solving & 2 & 22.2 \\
\hline 3. Discussion & 5 & 55.5 \\
\hline 4. Experimental & 4 & 44.4 \\
\hline 5. Learning by doing & 3 & 33.3 \\
\hline 6. Role-play & 2 & 22.2 \\
\hline
\end{tabular}

It reveals from Table 7.4 that a considerable number of teachers (44.4\%) believe that demonstration method and Experimental methods are the most effective method for elementary science teaching. The reason is, according to teachers, this method helps the student to learn easily and student can learn with fun and pleasure. It also enhances effective learning. However, others suggested experiments, learning by doing and observation as the most effective method.

Moreover, on the question of use of teaching aids in the classroom, almost all the teachers $(100 \%)$ claimed that they used teaching aids at the time of teaching in the classroom. The responses are shown in Table 7.5.

Table 7.5. Use of Teaching Aids by Teachers in the Classroom

\begin{tabular}{|c|c|c|c|c|c|c|}
\hline \multirow{2}{*}{ Teaching Aids } & \multicolumn{6}{|c|}{ Ratings \% } \\
\cline { 2 - 7 } & \multicolumn{2}{|c|}{ Never } & \multicolumn{2}{c|}{ Sometimes } & \multicolumn{2}{c|}{ Always } \\
\cline { 2 - 7 } & CT & St & CT & St & CT & St \\
\hline Maps/Globes & 11.1 & 40 & 22.2 & 20 & 66.7 & 40 \\
\hline Charts/pictures & 0.0 & 0.0 & 11. & 60 & 88.8 & 40 \\
\hline Scientific apparatus & 100 & 100 & 0.0 & 0.0 & 0.0 & 0.0 \\
\hline Real objects & 0.0 & 40 & 11.2 & 20 & 88.8 & 40 \\
\hline Models & 0.0 & 40 & 33.3 & 40 & 66.7 & 20 \\
\hline
\end{tabular}

It is found from the teacher's opinion that, maps/globes are frequently used. But most of the students (40\%) did not support this view. Most of them (40\%) opine that, teachers do not use maps/globes at all. The same thing happened in the case of charts/pictures. While the majority (88.8\%) of teachers opines that they always use charts/pictures in the class, most of the students (60\%) discoursed that their teacher uses charts/pictures occasionally. On the other hand, models and real objects are told to be sometimes used but $40 \%$ student declared their view against these opinions. However, scientific apparatus is not used at all. These views have been found true from the classroom observation.

\subsection{Situation of Students' Participation in the Classroom}

It is found from the collected data that, most of the teachers $(77.7 \%)$ engage student in classroom activity which is also supported by the student (80\%) as well. A considerable number of teachers $(77.7 \%)$ engage the student to use the chalkboard. On the other hand, the majority of the teachers (55.5\%) opine that students don't always participate in group work. They do it sometimes.

\subsection{Situation of Assessment Procedures Used for Elementary Science}

The teacher and student were asked about formative assessment e.g. whether the teacher assess the student in everyday class or not. All the teachers said that, they assess their students regularly. However, they were asked about their procedures for assessing the students. They mentioned the following procedures:

- Oral assessment (asking questions)

- Written assessment (fill in the blanks, answering questions, multiple choice, writing on the chalkboard, drawing)

In addition, Teacher and student's opinion were taken regarding homework. As their opinion, almost all the teacher gives homework regularly and their views have been supported by most of the (80\%) students. However, when they were asked about the category of their homework, most of the teachers $(80 \%)$ claimed that the homework given by them are sometimes creative and sometimes from the book but their view have been ignored by most of the students (60\%). They opine that their teacher gives homework from the chapter of the book.

\section{Major Findings}

Major findings are presented on three research questions based on analysis and interpretation of the study.

\subsection{What is the Present Situation of Knowledge, Training and Classroom Activities of the Elementary Science Teachers of Dhaka City?}

In every sample institutions, there are trained teachers with B.Ed, M.Ed and C.in.Ed. degrees. As none of the schools has any teachers only for elementary science and though the distribution of classes in the school routine is made considering the teachers' subject knowledge and skill, majority of have to take 6 to 7 classes per day in average and have to take Primary Math, English, Religious subjects, Bangla and sometimes baby classes as well.

Moreover, most of the class teachers always entered into the classroom on time. Nevertheless, $10 \%$ student said that, their teacher never comes in the classroom in time. Most of the teacher uses question-answer method and lecture method during classroom teaching and learning. According to the teachers question-answer method is appreciated for make students' attention towards their lesson. However, A significant number of respondents also reported that teachers do not give special attention to attract students towards lesson. Furthermore, Majority of the teachers do not use lesson plan as class preparation but maximum teachers have the capability of making the student understand the subject and motivate them without using the lesson plan properly.

\subsection{What is the Present Situation of Teaching Methods and Strategies Practiced in the Elementary Science Classrooms of Dhaka City?}

The opinion of teacher and student did not match in the case of proper application of teaching methods. While fewer teachers believe that they can apply elementary 
science teaching methods perfectly, most of the students are saying that the teachers can apply with a great deal. Majority of teachers dictates from the textbooks and summarize it at the end of the class. However, these teachers believe that demonstration method is the most effective method for elementary science teaching. The reason is, according to teachers, this method helps the student to learn easily and student can learn with fun and pleasure. Others suggested experiments, learning by doing and observation as the most effective method. As teaching strategy most of the teachers engage student in classroom activity. A considerable number of teachers engage the student to use the chalkboard. On the other hand, the majority of the teachers opine that students don't always participate in group work. Additionally, All teachers provide individual help to students and all of them also give attention to weaker students. It is found that maps/globes are frequently used as teaching aids. But most of the students did not support this view. They opine that, teachers do not use maps/globes at all. The same thing happened in the case of charts/pictures. While the majority of teachers opine that they always use charts/pictures in the class, most of the students discoursed that their teacher uses charts/pictures occasionally. On the other hand, models and real objects are told to be sometimes used but considerable number of students declared their view against these opinions. However, scientific apparatus is not used at all.

\subsection{What Kind of Assessment Procedures are Used for Elementary Science Teaching?}

All the teachers assess the student regularly. Most of them mainly use Oral assessment (asking questions) and Written assessment (fill in the blanks, answering questions, multiple choice, writing on the chalkboard, drawing) by taking First terminal, second terminal and annual examinations and sometimes weekly and model tests. Moreover Almost all the teacher gives homework regularly The homework given by them are sometimes creative and sometimes from the book but in contrast students said that, their teacher gives homework from the chapter of the book.

\section{Discussion of the Study}

Haque (1976) states “About $88 \%$ of science teachers in Dhaka city had general academic qualifications but 55\% of them had no professional qualifications [5].” But the study reveals $44.44 \%$ have got C.in.Ed degree, $77.77 \%$ have got B. Ed degree and $22.22 \%$ have got M.Ed degree. On this basis, it can be said that the professional training of teachers has increased significantly. Levitt (1994) suggested that science teachers should use student centered teaching strategies. The study revealed that most of the teacher used question-answer method during classroom teaching and learning and sometimes used lecture method which is quite satisfactory. Again it was found that the suggestions of Levitt (1994) had been applied by the teachers in some other cases, like most of the time teachers tried to maintain class discipline and make students' attention towards their lesson [7]. They also motivated the students regarding science learning, appreciated them while they gave correct answer to questions, provided individual help to students and gave attention to weaker students. However, the researchers believes that the above facts might be the reason behind other disappointing findings like teachers did not give special attention to attract students towards lessons, they didn't create opportunity for group discussion, some teachers were unable to show their lesson plans, some showed a short lesson plan. The collected data also disclosed that maximum teachers had the capability of making the students understand the subject, they had the competence of answering questions correctly which is similar to Outstanding teaching requires teachers to have a deep understanding of the subject matter and its structure, as well as an equally through understanding of the kinds of teaching activities that help students understand the subject matter in order to be capable of asking probing questions [3]. From the research it was also found that a considerable number of teachers believed that demonstration method is the most effective method for elementary science teaching. Majority of teachers opined do not always use charts/pictures in the class. This result is quite similar with Bari (2007) where he claimed that in most of the schools teachings-aids were not available and those schools where these were available were not usable due to absence of proper storage [1]. In addition, teachers gave homework regularly and they claimed that the homework given by them were sometimes creative and sometimes from the book. Such kind of formative assessment is more effective in teaching elementary science as Sarkar (1995) found in his study that formative assessment system is more effective than traditional methods [10].

\section{Concluding Remarks}

There is no alternative of learning Elementary science for the development of a country like Bangladesh where natural disasters, environmental degradation relating to land, water, forest, and other natural resources are a common scenario. But, before taking steps to increase the quality of Elementary science, the need of the students should be identified and the current situation of teaching of Elementary science should be discovered. The researcher hope that, by this study, the educators, curriculum and textbook planners, teacher's trainers will be able to know what kind of books and methods students like to learn regarding Elementary Science.

\section{References}

[1] Bari, N. (2007). To find the utility of teaching aids developed by Directorate of Environment to teach environmental science. Unpublished masters' thesis, Institute of Education and Research, University of Dhaka, Dhaka, Bangladesh.

[2] Begum, H. A. (1981). Determination of attitudes of grade 5 students of primary school towards environmental education. Unpublished masters' thesis, Institute of Education and Research, University of Dhaka, Dhaka, Bangladesh.

[3] Bransford J. D., Brown, A. L., \& Cocking, R. R., eds (1999). How People Learn: Brain, Mind, Experience, and School.Washington, DC: National Academy Press.

[4] Dickie, L. O., Dedic, H., Rosenfield, S., Rosenfield, E., Simon, R. A., (2006). Success and Persistence in Science: The Influence of Classroom. Retrieved June 15, 2012, from http://arxiv.org/ftp/physics/papers/0610/0610243.pdf 
[5] Haque, A. (1976). An evaluation of present condition of science education at secondary schools of Dhaka city. Unpublished masters' thesis, Institute of Education and Research, University of Dhaka, Dhaka, Bangladesh.

[6] Lee, Y. (2010). Cultural Perspective in Science Education. In Ken, T. and Roth, W. (Ed.), Handbook of Research in Science Education Research in Asia. Retrieved June 15, 2012, from https:/www.sensepublishers.com/files/9789460910746PR.pdf.

[7] Levitt, T. C (1994). Strategies for adapting science textbooks for youth with learning disabilties. Remedial and Special Education, 15, 105-116.

[8] Masood, S.S. (2007). Better Physics Teaching Can Increase Physics Enrollment. Retrieved June 15, 2012, from http://arxiv.org/abs/physics/0702089.

[9] Miah, M. B. (2011). Current Situations of Basic Education in Bangladesh. Retrieved June 15, 2012, from http://www.criced.tsukuba.ac.jp/pdf/06_Bangladesh_Badal.pdf.

[10] Sarkar, P. (1995) Effectiveness of formative assessment in enhancing the quality of Elementary Science in the Primary Schools. Unpublished masters' thesis, Institute of Education and Research, University of Dhaka, Dhaka, Bangladesh.

[11] Sultana, S. (2008). A Study of English Language TeachingLearning Situation among the Garo Tribe and Mainstream Schools of Bangladesh. Unpublished masters' thesis, Institute of Education and Research, University of Dhaka, Dhaka, Bangladesh. 